\section{Hoe kiezen we straks de burgemeester? Over de voor- en nadelen van verschillende verkie- zingsprocedures}

\section{Henk van der Kolk}

Dr. Henk van der Kolk is als universitair docent Politicologie verbonden aan de faculteit Bedrijf, Bestuur en Technologie (BBT) van de Universiteit Twente. Hij publiceerde onder meer Electorale controle (1997), en samen met anderen Politieke veranderingen in Nederland 1971-1998 (2000) en Lokale kiesstelsels vergeleken (2002). In zijn onderzoek richt hij zich vooral op de relatie tussen (electorale) instituties en (politiek) gedrag.

Adres: Universiteit Twente, faculteit Bedrijf, Bestuur en Technologie (BBT), leerstoel politicologie, postbus 217, 7500 AE Enschede, tel.: 053 4893281, e-mail: H.vanderkolk@utwente.nl

meeste stemmen worden gekozen. Als een gekozen burgemeester wordt geïntroduceerd in ons staatsbestel is dat een unieke procedure omdat er per gemeente maar één persoon wordt gekozen. Deze procedure zal wellicht een standaard zetten voor latere veranderingen in het Nederlandse staatsbestel. Daarom mag bij de keuze voor deze procedure niet over één nacht ijs worden gegaan.

In de Verkennende notie over de invoering van de direct gekozen burgemeester wordt kort verwezen naar de verkiezingsprocedure (BZK 2003a). Na het noemen van twee alternatieve procedures (het tweerondesysteem en het systeem van de alternative vote, zie ook hieronder) wordt zonder verdere toelichting geconcludeerd dat 'vanwege de grotere inzichtelijkheid en eenvoud (...) het tweerondesysteem de voorkeur (verdient)' (BZK 2003a, 36). In de hoofdlijnennotitie van september 2003 wordt uitvoeriger ingegaan op dit onderwerp en worden ook enkele andere stelsels behandeld (BZK 2003b), maar in het advies van de kiesraad naar aanleiding van deze hoofdlijnennotitie wordt geconcludeerd dat ook daarin slechts 'op zeer rudimentaire wijze' is gesproken over verkiezingsprocedures. Vervolgens gaat de raad zelf wel iets uitvoeriger in op 
enkele mogelijke procedures. Daarbij wordt een voorkeur uitgesproken voor het tweerondesysteem (Kiesraad 2003).3 Ook de Raad voor het Openbaar Bestuur neigt naar het steunen van een tweerondesysteem (BZK 2003C).

$\mathrm{Nu}$ zijn er naast de in de discussie genoemde systemen nog wel meer mogelijke procedures. Zo kunnen bijvoorbeeld ook de regel van Coombs of de regel van Copeland worden gehanteerd. Deze en dergelijke regels worden feitelijk wel gehanteerd, maar vaak alleen door bijvoorbeeld vakbonden, politieke partijen en vakorganisaties (Felsenthal, Maoz e.a. I993; Felsenthal en Machover I995).

Deze procedures kunnen natuurlijk niet alleen op grond van hun 'inzichtelijkheid en eenvoud' worden beoordeeld.4 Zo kunnen procedures ook worden beoordeeld naar de mate waarin zij altijd de meerderheidswinnaar selecteren, de mate waarin zij een zogenaamde condorcetwinnaar altijd selecteren en de condorcetverliezer nooit selecteren. Ook kan bijvoorbeeld worden gëeist dat een kandidaat nooit voordeel mag hebben bij het halen van minder stemmen of dat de gebruikte procedure niet vatbaar mag zijn voor strategisch gedrag van (groepen) kiezers.

Verkiezingsprocedures zijn niet neutraal, en sommige procedures zijn beter op grond van sommige criteria, terwijl ze juist weer slechter zijn op grond van andere criteria. Bij elke regel moeten problemen worden geaccepteerd: problemen die te maken hebben met de selectie van de 'juiste' burgemeester of problemen met de eisen die aan kiezers worden gesteld. De manier waarop de burgemeester rechtstreeks moet worden gekozen, verdient dan ook meer dan terloopse aandacht.

In deze bijdrage worden aan de hand van een fictief voorbeeld eerst vier verschillende verkiezingsprocedures besproken (het simpele meerderheidsstelsel, het tweerondesysteem, alternative vote en de regel van Coombs). Daarbij wordt duidelijk dat verschillende verkiezingsprocedures verschillende resultaten kunnen opleveren (paragraaf I). Daarna worden zeven criteria gepresenteerd, waaronder aspecten van 'inzichtelijkheid en eenvoud', die ook een rol in de discussie zouden kunnen spelen (paragraaf 2). Aan de hand van deze criteria worden de vier besproken procedures beoordeeld (paragraaf 3). Aansluitend richten we ons op een stelsel dat het in het licht van de hier besproken criteria beter lijkt te doen dan de vier eerder besproken procedures: de aangevulde regel van Copeland. Ook deze procedure wordt eerst besproken en vervolgens beoordeeld (paragraaf 4). In de laatste paragraaf worden enkele conclusies getrokken (paragraaf 5).

\section{Vier procedures, vier winnaars}

Verkiezingsprocedures zorgen ervoor dat uit twee of meer kandidaten uiteindelijk een burgemeester wordt gekozen. We zullen zien dat dit op verschillende manieren kan. Maar voordat we deze procedures de revue laten passeren, moet duidelijk worden gemaakt dat er eigenlijk geen probleem is als er maar twee kandidaten meedoen aan de verkiezingen. Alle procedures die hierna aan bod komen, wijzen dan dezelfde burgemeester aan. Het onderstaande is dan ook niet relevant voor de zogenoemde burgemeestersreferenda. Daaraan doen immers maar twee kandidaten mee die worden geselecteerd door de gemeenteraad. De dingen veranderen pas als er drie of meer kandidaten meedoen. ${ }^{5}$

Bij de presentatie van de eerste vier procedures veronderstellen we dat er in een gemeente vier kandidaten meedoen aan verkiezingen. Kiezers plaatsen die kandidaten voor zichzelf in een volgorde. Om dit inzichtelijk te houden, veronderstellen we voorlopig dat er maar vier voorkeursvolgordes voorkomen in deze gemeente. De argumentatie zou nodeloos ingewikkeld worden als we ook allerlei andere volgordes in ogenschouw zouden nemen. ${ }^{6}$ In tabel I zijn de voorkeuren van de vier groepen kiezers (het 'profiel' van het electoraat in deze gemeente) weergegeven.

Tabel 1: De voorkeuren van vier groepen kiezers voor vier burgemeesterkandidaten

\begin{tabular}{|l|c|c|c|c|}
\hline Groep & I & j & k & I \\
\hline Omvang & $12 \%$ & $25 \%$ & $49 \%$ & $14 \%$ \\
\hline Eerste voorkeur & $\mathrm{a}$ & $\mathrm{y}$ & $\mathrm{x}$ & $\mathrm{z}$ \\
\hline Tweede voorkeur & $\mathrm{z}$ & $\mathrm{a}$ & $\mathrm{a}$ & $\mathrm{a}$ \\
\hline Derde voorkeur & $\mathrm{y}$ & $\mathrm{z}$ & $\mathrm{y}$ & $\mathrm{y}$ \\
\hline Vierde voorkeur & $\mathrm{x}$ & $\mathrm{x}$ & $\mathrm{z}$ & $\mathrm{x}$ \\
\hline
\end{tabular}

De meeste stemmen gelden: kandidaat $\mathrm{x}$ wint 
De makkelijkste procedure voor het kiezen van een burgemeester is het eenvoudige meerderheidsstelsel, ook wel het 'first-past-the-post'- of 'plurality' systeem genoemd (Riker I982, 85). Kiezers hoeven volgens deze procedure alleen maar aan te geven wie van de gegeven kandidaten zij de beste vinden. Het stelsel wordt onder meer gebruikt in sommige landen met een districtenstelsel, waarbij per district één kandidaat wordt aangewezen.

Omdat we in deze bijdrage voorlopig veronderstellen dat kiezers hun voorkeuren oprecht opgeven en zich niet strategisch gedragen (waarover later meer), wint in onze voorbeeldgemeente kandidaat $x$. Deze heeft immers de meeste stemmen (49 procent). De kandidaten $a, y$ en $z$ moeten het doen met respectievelijk I2, 25 en I4 procent van de stemmen.

Twee kandidaten strijden opnieuw: kandidaat $y$ wint Alternatief voor de simpele meerderheidsregel is een systeem met twee ronden, ook wel 'run-off elections' genoemd. Dit systeem wordt in onder andere Frankrijk gehanteerd bij verschillende verkiezingen. Tot I9I7 werd het ook in Nederland gebruikt bij het kiezen van leden voor de Tweede Kamer. Bovendien wordt dit systeem zoals gezegd voorgesteld in de Verkennende notitie invoering direct gekozen burgemeester van het Ministerie van BZK. Ook bij dit stelsel geven kiezers aan wie zij gekozen willen zien tot burgemeester. Als één van de kandidaten meer dan 50 procent van de stemmen binnenhaalt, is hij direct gekozen. Indien geen van de kandidaten in de eerste ronde een meerderheid haalt, wordt een tweede ronde gehouden. Aan deze tweede ronde mogen alleen de twee kandidaten meedoen die in de eerste ronde de meeste stemmen haalden.

In ons voorbeeld (zie wederom tabel I) wint geen van de kandidaten de eerste ronde. Daarvoor is immers meer dan 50 procent van de stemmen nodig. De kandidaten $x$ (49 procent) en $y$ ( 25 procent) doen daarom mee aan een tweede ronde. Als de voorkeuren van kiezers in de tussenliggende periode ongewijzigd zijn gebleven, wordt kandidaat $x$ in de tweede ronde verslagen door kandidaat $\gamma$. Kandidaat $y$ krijgt immers $5^{\mathrm{I}}$ procent van de stemmen terwijl kandidaat $x$ maar 49 procent wint.

\section{Ook de andere voorkeuren tellen mee: kandidaat $\mathrm{z}$ wint}

In Australië wordt het zogenaamde systeem van de alternative vote gebruikt.7 Dit systeem wordt ook wel 'het systeem van Hare' of 'preferential vote' genoemd. ${ }^{8}$ In de Verkennende notitie invoering direct gekozen burgemeester wordt dit alternatief ter zijde geschoven omdat het ten opzichte van het tweerondesysteem niet inzichtelijk en eenvoudig zou zijn. Dit oordeel lijkt vooral te zijn ingegeven door de extra eis die aan kiezers wordt gesteld. In tegenstelling tot in het tweerondesysteem en het eenvoudige meerderheidsstelsel moeten kiezers hier namelijk niet alleen aangeven welke kandidaat ze de beste vinden, maar ook welke kandidaat op de tweede plaats komt en welke op de derde, et cetera.99

Het verwerken van de stemmen is vrij simpel. Als een van de kandidaten door meer dan de helft van de kiezers op de eerste plaats wordt gezet, heeft hij direct gewonnen. Indien geen van de kandidaten meer dan 50 procent van de stemmen heeft, valt de kandidaat af die door de minste kiezers bovenaan is geplaatst. Dan wordt gekeken naar de tweede voorkeur van deze groep kiezers. Opnieuw wordt dan bezien of er een kandidaat is met een meerderheid. Als die er niet is, wordt wederom de kandidaat met de minste stemmen geschrapt en wordt van de kiezers die deze kandidaat nu bovenaan hadden staan de volgende voorkeur meegeteld.

In ons voorbeeld (zie weer tabel I) wint geen van de kandidaten direct een meerderheid. Daarom doet kandidaat $a$, die slechts door I2 procent van de kiezers boven aan werd geplaatst, niet langer mee. De stemmen van groep $i$ (kiezers die kandidaat $a$ bovenaan hadden staan) worden opgeteld bij de stemmen voor kandidaat $z$ (de tweede voorkeur van groep i). Nu heeft kandidaat $y 25$ procent van de stemmen, kandidaat $z 26$ procent en kandidaat $x$ nog steeds 49 procent. Nog steeds heeft geen van de kandidaten een meerderheid en dus valt kandidaat $y$ af. Deze kandidaat heeft nu immers minder stemmen dan kandidaat $z$. De stemmen van kandidaat $\gamma$ (groep $j$ ) gaan niet naar kandidaat $a$, want die doet al niet meer mee, maar naar kandidaat $z$. Deze verwerft daarmee $5^{\mathrm{I}}$ procent van de stemmen en wint de verkiezing. 


\section{De minst gewaardeerde kandidaat}

valt het eerste af: kandidaat a wint

Indien we kiezers vragen niet alleen hun eerste, maar ook hun tweede, derde en vierde voorkeur op te geven, staat daarmee de gekozen kandidaat nog niet direct vast. Zo is er een variant op de alternative vote, die uitgaat van de vraag welke kandidaat het vaakst onderaan wordt geplaatst: het systeem van Coombs. Ook nu plaatsen kiezers de kandidaten weer in volgorde. Eerst wordt bekeken of er een kandidaat is die door de meer dan 50 procent van de kiezers bovenaan wordt geplaatst. Als die er niet is, wordt gekeken naar de kandidaat die door de meeste kiezers onderaan is geplaatst. Die kandidaat valt af. Daarna wordt opnieuw bekeken of er een kandidaat is die door meer dan 50 procent van de kiezers bovenaan wordt geplaatst. Als die er niet is, wordt gekeken wie van de overblijvende kandidaten het vaakst onderaan is geplaatst. Dit gaat net zolang door totdat nog maar een van de kandidaten over is (Mueller I989, II2).

In ons voorbeeld heeft geen van de kandidaten al direct een meerderheid. Daarom wordt bekeken welke kandidaat door de meeste kiezers onderaan wordt gezet: dat blijkt kandidaat $x$ te zijn. Deze kandidaat valt dus als eerste af. Omdat deze kandidaat afvalt, wordt van groep $k$ de tweede voorkeur (kandidaat $a$ ) in de berekening betrokken. Gevolg is dat kandidaat a met 6I procent van de stemmen tot winnaar wordt uitgeroepen.

\section{Vier procedures, vier burgemeesters}

Eén verkiezing, vier kandidaten, vier procedures en vier verschillende burgemeesters. We zien dus dat procedures een enorme impact kunnen hebben. In ons fictieve voorbeeld veranderden de voorkeuren van kiezers immers niet. Slechts de manier waarop die voorkeuren werden vertaald in een burgemeester is telkens anders. Procedures zijn dus niet neutraal.

\section{Zeven eisen aan een verkiezingsprocedure}

Welke van deze en andere procedures is nu de meest redelijke? Welke procedure vertaalt met andere woorden de voorkeuren van de bevolking het beste? En welke procedures kunnen leiden tot bijzonder vreemde en ongewenste uitkomsten? Om een antwoord op deze vragen te kunnen geven, moeten we eerst preciezer omschrijven wat we bedoelen met bijzonder vreemde en ongewenste uitkomsten. Welke eisen kunnen we met andere woorden stellen aan de verkiezingsprocedure?

Allereerst kan worden betoogd dat het te gebruiken stelsel een uitwerking moet zijn van het idee dat de kandidaat die de meerderheid krijgt ook moet winnen. Als niet wordt voldaan aan deze simpele eis zou een minderheid kunnen bepalen wie er burgemeester wordt en dat zou door sommigen ongewenst kunnen worden gevonden.

De eerste eis die dit simpele en abstracte idee concretiseert, is dat een burgemeesterskandidaat die meer dan 50 procent van de stemmen haalt (dat wil zeggen: door meer dan 50 procent van de kiezers de beste wordt gevonden) ook burgemeester moet worden. We noemen dit criterium de eis dat de meerderheid bepaalt (Nurmi I987, 62). Een kandidaat die door meer dan de helft van de kiezers op de eerste plaats wordt gezet, noemen we een 'meerderheidswinnaar'. Een probleem is natuurlijk dat er lang niet altijd een meerderheidswinnaar is. Zo wordt in ons fictieve voorbeeld (zie wederom tabel I) geen van de kandidaten zonder meer gesteund door meer dan 50 procent van de kiezers.

De tweede eis en derde eis zijn wat zwakker, maar sterk verwant met de eerste. Deze eisen zouden kunnen worden opgevat als een uitbreiding van de meerderheidseis voor situaties waarin geen van de kandidaten wordt gesteund door meer dan 50 procent van de kiezers. Om deze eisen wat duidelijker te maken, stellen we ons voor dat de vier burgemeesterkandidaten uit ons voorbeeld het voor de verkiezingen opnemen tegen telkens een van de andere kandidaten. Elk van de kandidaten moet het dus paarsgewijs opnemen tegen de andere drie. Een kandidaat die in die paarsgewijze strijd alle keren wint en dus telkens zijn tegenstander verslaat wordt wel de condorcetwinnaar genoemd. ${ }^{\circ}$ Een tweede eis die we aan een stemprocedure, stellen luidt dat een condorcetwinnaar burgemeester moet worden. Het zou immers vreemd zijn dat een burgemeester die wordt afgekeurd door een meerderheid van de kiezers, wel de verkiezingen wint. In dat geval tellen immers de stemmen van sommige mensen meer dan de stemmen van anderen. ${ }^{\text {II }}$ Sterk verwant met deze tweede eis is de derde eis dat de condorcetverliezer (de kandidaat die álle paarsgewijze verkiezingen verliest) in ieder geval níet tot burgemeester mag worden gekozen. ${ }^{\text {I2 }}$ 
Een vierde eis is die van 'monotoniciteit' (Riker I982, 45 en 78; Nurmi i987, 67). Deze eis luidt dat áls een electoraat kandidaat $x$ verkiest boven kandidaat $\gamma$ (bijvoorbeeld een week voor de verkiezingen) en een deel van de kiezers vervolgens zijn voorkeuren zodanig verandert dat zij $x$ (de winnaar!) nu beter vindt (bijvoorbeeld omdat deze kandidaat een geweldige verkiezingstoespraak houdt), het niet zo mag zijn dat vervolgens kandidaat $\gamma$ wint. Deze eis wordt zo belangrijk gevonden dat schending ervan in de literatuur wel 'pervers' wordt genoemd (Doron en Kronick 1977). Als de procedure die we gaan gebruiken bij het kiezen van de burgemeester niet voldoet aan deze eis, kan het gebeuren dat de lokale krant moet vaststellen:

Eric Helder won vandaag niet de burgemeestersverkiezingen van Enschede. Maar als nu 5000 van zijn trouwe supporters hem op de tweede in plaats van op de eerste plaats zouden hebben gezet, zou hij deze verkiezingen wel hebben gewonnen!

Dit laatste wijst ons ook op een vijfde belangrijke eis die aan deze en dergelijke procedures zou kunnen worden gesteld. Het gaat hier om de mate waarin kiezers 'strategisch' kunnen stemmen. Hiervoor zijn we er immers vanuitgegaan dat kiezers hun werkelijke, oprechte voorkeuren gebruiken bij het uitbrengen van hun stem. Maar die veronderstelling gaat voorbij aan de intelligentie van kiezers. Als de kiezers uit ons voorbeeld (tabel I) de meerderheidsregel moeten gebruiken, zullen veel van hen waarschijnlijk niet op de kandidaat stemmen die zij 'de beste' vinden. Indien de kiezers in de groepen $i$ en $l$ immers van tevoren weten dat hun kandidaat geen kans maakt (bijvoorbeeld omdat er opiniepeilingen zijn gehouden), stemmen ze wellicht op kandidaat $\gamma$. Die hebben ze immers liever dan kandidaat $x$. Sommige verkiezingsprocedures maken het kiezers gemakkelijker strategisch te stemmen dan andere. Er zou een moeilijk te manipuleren procedure kunnen worden geëist. Een eenvoudig te manipuleren regel bevoordeelt immers de goed geïnformeerde kiezers boven de kiezers die simpelweg hun oprechte voorkeuren opgeven. ${ }^{13}$

Ook kunnen we net als het Ministerie van BZK eisen stellen aan inzichtelijkheid en eenvoud van de regel. Nu zijn 'inzichtelijkheid en eenvoud' vrij vage aanduidingen. De termen kunnen onder meer betekenen dat er niet te veel van kiezers moet worden geëist. In dat licht zijn procedures die van kiezers alleen vragen wie ze de beste burgemeesterskandidaat vinden 'eenvoudiger' dan procedures die ook om een tweede, derde, et cetera voorkeur vragen. Dit is een zesde eis. Toch moeten kiezers op dit punt niet worden onderschat. Dat blijkt bijvoorbeeld uit hun vermogen om zeer ingewikkelde stelsels te gebruiken bij de verkiezingen van een gemeenteraad (Kummeling en Van der Kolk 2002, 7I-74 en vooral voetnoot 22).

Ten slotte lijken procedures met maar één enkele stemronde het meest 'inzichtelijk en eenvoudig' voor zowel de kiezers als de gemeentelijke overheidsorganisatie. Zeker aan kiezers die in de eerste ronde hebben gestemd op een van de kandidaten die ook in een volgende ronde meedoen (dat zal in veel gevallen een groot deel van de bevolking zijn), kan het lastig zijn uit te leggen dat ze naar de stembus moeten om dat nogmaals te doen. Het organiseren van twee verkiezingen kan bovendien kostbaar zijn (Reynolds en Reilly I997, 44).

Overzicht 1: zeven eisen die kunnen worden gesteld aan een verkiezingsprocedure

1. Meerderheidswinnaar wordt altijd geselecteerd

2. Condorcetwinnaar wordt altijd geselecteerd

3. Condorcetverliezer wordt nooit geselecteerd

4. Het is nooit belangrijk minder stemmen te krijgen (monotoniciteit)

5. Procedure kan strategisch moeilijk worden gemanipuleerd (strategieneutraal)

6. Kiezers hoeven alleen op te geven welke kandidaat zij de beste vinden (eenvoud)

7. Er hoeft maar één keer gestemd te worden (kosten)

We kunnen natuurlijk nog meer eisen stellen aan verkiezingsprocedures, maar in deze bijdrage zien we daarvanaf. ${ }^{\mathrm{I}}$

\section{In welke mate voldoen de eerste vier verkiezingsprocedures aan deze eisen?}

Sinds de discussie naar aanleiding van de stelling van Arrow weten we dat geen énkele procedure voldoet aan enkele zeer eenvoudige eisen, waaronder 
enkele van de hiervoor genoemde. ${ }^{5}$ Bovendien weten we dankzij de stelling van Gibbard en Sattherwaite ook dat geen enkele procedure bestand is tegen elke vorm van strategisch gedrag. Toch betekent dit niet dat alle regels een pot nat zijn. Bij alle procedures kan het namelijk om verschillende redenen 'misgaan'. We kunnen dus zoeken naar regels die weliswaar op bepaalde punten disfunctioneren, maar het op andere punten juist heel goed doen. Verder kan ook de mate waarin het misgaat sterk verschillen. Bij onze analyse van de verschillende procedures laten we in het midden hoeveel belang aan elk van de eisen moet worden gesteld. Dat is een politieke keuze die in deze bijdrage verder niet wordt gemaakt.

\section{De meerderheidsregel}

De simpele stemprocedure waarbij 'de meeste stemmen gelden', voldoet in ieder geval aan de eerste eis: als meer dan vijftig procent van de stemmen wordt uitgebracht op een kandidaat, wint deze kandidaat de verkiezingen. De regel voldoet echter niet aan de eis dat er een condorcetwinnaar moet worden gekozen als die er is. Kijk maar naar tabel 2. Daarin staat uitgewerkt wie van de vier kandidaten in ons fictieve voorbeeld de condorcetwinnaar is.

Tabel 2: condorcetwinnaar in het fictieve voorbeeld (zie tabel 1) met vier burgemeesterkandidaten. Tussen haakjes staan de groepen kiezers (telkens een meerderheid) die de kandidaat steunen in een paarsgewijze vergelijking.

\begin{tabular}{|c|c|c|c|c|c|}
\hline & $a$ & $x$ & $y$ & $z$ & \\
\hline$a$ & - & $\begin{array}{l}a \\
(i, j e n l)\end{array}$ & $\begin{array}{l}\mathrm{a} \\
(i, k, l)\end{array}$ & $\begin{array}{l}a \\
(j, k)\end{array}$ & $\begin{array}{l}\text { a wint } 3 \text { keer } \\
\text { en is condorcet- } \\
\text { winnaar }\end{array}$ \\
\hline$x$ & $\begin{array}{l}a \\
(i, j e n l)\end{array}$ & - & $\begin{array}{l}y \\
(i, j e n l)\end{array}$ & $\begin{array}{l}z \\
(i, j e n l)\end{array}$ & $\begin{array}{l}\text { x verliest } 3 \text { keer: } \\
\text { condorcet- } \\
\text { verliezer }\end{array}$ \\
\hline$Y$ & $\begin{array}{l}\text { a } \\
(i, k, l)\end{array}$ & $\begin{array}{l}y \\
(i, j \text { en I) }\end{array}$ & - & $\begin{array}{l}y \\
(j, k)\end{array}$ & $\begin{array}{l}y \text { wint } 2 \text { keer } \\
\text { (van } x \text { en van } z)\end{array}$ \\
\hline Z & $\begin{array}{l}a \\
(j, k)\end{array}$ & $\begin{array}{l}z \\
(i, j e n l)\end{array}$ & $\begin{array}{l}y \\
(j, k)\end{array}$ & - & $\begin{array}{l}\text { z wint } 1 \text { keer } \\
\text { (alleen van } \\
\text { kandidaat } x \text { ) }\end{array}$ \\
\hline
\end{tabular}

Als kandidaat $a$ het opneemt tegen kandidaat $x$ wint kandidaat $a$ omdat de groepen $i, j$ en $l$ hem steunen. Uit tabel I blijkt dat deze groepen samen meer dan 50 procent van de stemmen vertegenwoordigen. Hieruit blijkt dat in ons fictieve voorbeeld kandidaat a de condorcetwinnaar is. Kandidaat $a$ wint immers de tweestrijd met elk van de andere kandidaten apart. De simpele meerderheidsregel wijst echter kandidaat $x$ als winnaar aan. Uit ons voorbeeld blijkt dus dat de meerderheidsregel soms níet de condorcetwinnaar aanwijst.

Maar hoe vaak komt dat nu voor? Is dat iets wat wellicht een keer kan gebeuren, of gebeurt het redelijk vaak? Hoe vaak schendt de meerderheidsregel met andere woorden de tweede eis? Om die vraag te beantwoorden, kunnen verschillende methoden worden gebruikt (Felsenthal, Maoz e.a. I993). ${ }^{16}$ Uit toepassing van die methoden blijkt dat de meerderheidsregel vrij vaak de eis schendt dat altijd de condorcetwinnaar moet worden gekozen (Merrill I984). Zeker als het aantal kandidaten toeneemt, is de kans dat de condorcetwinnaar niet wordt gekozen bijzonder groot. De drie procedures die we hieronder bespreken, doen het op dit punt altijd beter.

Zoals uit het voorbeeld hierbovenblijkt, schendt de meerderheidsregel ook de derde eis. In ons voorbeeld (zie wederom tabel 2) wordt immers de burgemeesterskandidaat die het moet afleggen tegen álle tegenkandidaten afzonderlijk (een condorcetverliezer) met de meerderheidsregel toch gekozen tot burgemeester!

Aan de vierde eis wordt weer wel voldaan. Kandidaten hoeven dan ook niet bang te zijn dat het winnen van méér stemmen hun kans op de eindoverwinning doet afnemen. We lichten dat hier verder niet toe. De vijfde eis, die van 'strategieneutraliteit', wordt door de meerderheidsregel wel weer relatief vaak geschonden. ${ }^{\mathrm{I} 7}$ Kiezers hoeven immers alleen de eerste voorkeuren van andere kiezers te kennen om iets aan de uitkomsten te veranderen (Nurmi i987, I24).

Dit alles neemt niet weg dat de procedure voor kiezers eenvoudig is (ze hoeven alleen de beste kandidaat door te geven). Bovendien hoeven kiezers maar één keer naar de stembus. Deze procedure voldoet dus wel aan de zesde en zevende eis. 


\section{Het tweerondesysteem}

Onder meer omdat de meerderheidsregel lang niet altijd de condorcetwinnaar aanwijst, is in het verleden gepleit voor het 'tweerondesysteem'. Deze procedure voldoet aan de eis dat altijd de meerderheidskandidaat moet worden geselecteerd. Maar de condorcetwinnaar wordt met behulp van deze procedure ook niet altijd gekozen. Dat blijkt uit ons fictieve voorbeeld. Kandidaat $a$ is immers de condorcetwinnaar, terwijl kandidaat $y$ in een tweerondensysteem de verkiezing wint. De omvang van het probleem is echter niet zo dramatisch als bij het simpele meerderheidsstelsel (Merrill I984, 31 e.v.). ${ }^{18}$ Ook wordt bij het tweerondesysteem nooit een condorcetverliezer worden geselecteerd: ongeacht de selectie in de eerste ronde zal in de tweede ronde een condorcetverliezer het altijd afleggen tegen zijn tegenstander. De procedure voldoet dus wel aan de derde eis.

Nog belangrijker is wellicht dat het systeem van twee ronden ook de eis van 'monotoniciteit' schendt. Zoals we hierboven uiteen hebben gezet, luidt deze vierde eis dat als een electoraat kandidaat $x$ verkiest boven kandidaat $y$ en een deel van de kiezers vervolgens zijn voorkeuren zodanig verandert dat het nu $x$ (nog) beter vindt, het niet zo mag zijn dat $\gamma$ vervolgens wint. Het systeem met twee kiesronden schendt echter deze eis en kan dus 'pervers' worden genoemd. Op het punt van de strategieneutraliteit lijkt het tweerondesysteem het daarentegen weer beter te doen dan de simpele meerderheidsregel (Nurmi i987, 124). ${ }^{\text {I9 }}$

Voor wat betreft inzichtelijkheid en eenvoud scoort het tweerondesysteem slechter dan het simpele meerderheidsstelsel. Weliswaar hoeven kiezers ook nu per verkiezing alleen de beste kandidaat op te geven (eis 6), maar daar staat tegenover dat kiezers in sommige gevallen twee keer naar de stembus moeten. Deze regel voldoet dus niet aan de zevende eis.

\section{Alternative vote}

Weliswaar wordt met de alternativevote-regel altijd de meerderheidskandidaat gekozen als die er is, maar zoals uit ons leidende voorbeeld blijkt, kan het gebeuren dat de condorcetwinnaar niet altijd wordt gekozen. Volgens de alternativevote-regel wordt immers kandidaat $z$ geselecteerd, terwijl kandidaat $a$ de condorcetwinnaar is. In de mate waarin condorcetwinnaars niet worden gekozen, is hier overigens onder de meeste omstandigheden nauwelijks verschil met het stelsel met twee ronden (Merrill I984, 29, 34 en 35). Ook wordt nooit de condorcetverliezer gekozen. Alternative vote voldoet dus ook aan de derde gestelde eis. En waar het gaat om de monotoniciteit van de regel, is er ook al geen verschil met het tweerondesysteem: ook alternative vote schendt de eis van monotoniciteit. Het tweerondesysteem en de alternative vote zijn op deze eerste vier punten dus gelijkwaardig.

De meningen over de mate waarin het tweerondesysteem en alternative vote relatief gevoelig zijn voor strategisch gedrag, zijn verdeeld. Volgens bijvoorbeeld Nurmi zijn ook op dit punt de regels identiek, maar Dummett vertoont een relatieve voorkeur voor alternative vote (Dummett I997, $90)$ : alternative vote verlaagt volgens hem de mogelijkheid om strategisch te stemmen ten opzichte van het tweerondesysteem.

Als de keuze wordt beperkt tot het tweerondesysteem en de alternative vote is het dus niet vreemd dat vooral wordt gekeken naar 'inzichtelijkheid en begrijpelijkheid'. Want op dit punt verschillen deze twee systemen wel duidelijk. Zo wordt bij een systeem van alternative vote van kiezers geëist dat zij meer opgeven dan alleen de beste kandidaat. Daarmee voldoet deze regel niet aan de zesde eis. ${ }^{20}$ Daar staat tegenover dat kiezers maar één keer naar de stembus hoeven, terwijl ze in een tweerondesysteem soms twee keer naar de stembus moeten. Daarmee voldoet deze procedure weer wel aan de zevende eis.

\section{Regel van Coombs}

Met de regel van Coombs wordt altijd de meerderheidswinnaar geselecteerd. Verder blijkt dat in ons voorbeeld (tabel I en 2) alleen de regel van Coombs de condorcetwinnaar selecteert. Dat is niet toevallig, want de regel van Coombs doet dat in het algemeen beduidend vaker dan de drie andere regels (Merrill I984). Toch faalt de regel van Coombs weleens op dit punt: dan wordt de condorcetwinnaar niet geselecteerd. Wel wordt, net als in het tweerondesysteem en alternative vote, nooit een condorcetverliezer geselecteerd.

De regel van Coombs voldoet verder net zomin als het tweerondesysteem en alternative vote aan de eis van monotoniciteit (Nurmi I983, I95). De 
mogelijkheid om de regel strategisch in te zetten, lijkt net zo beperkt als bij alternative vote en het systeem met twee ronden (Nurmi 1987, I24). De begrijpelijkheid en inzichtelijkheid zijn net zo groot als van het systeem van alternative vote (maar wellicht kleiner dan van het tweerondesysteem omdat de kandidaten in een bepaalde volgorde moeten worden geplaatst). De uitvoering voor degenen die stemmen moeten tellen, verschilt ook niet van alternative vote, want er hoeft maar één keer te worden gestemd.

\section{Welke regel is beter dan de vier al besproken procedures in het licht van de zeven criteria?}

We kunnen onze analyse nu uitbreiden tot een groot aantal andere stemprocedures. ${ }^{2 I}$ Voor de inzichtelijkheid van de analyse en omdat de Nederlandse discussie zich vooralsnog vooral lijkt te richten op alternative vote en het tweerondesysteem, beperken we ons echter tot regels die het op grond van de hierboven genoemde criteria ten minste even goed lijken te doen als het tweerondesysteem, de alternative vote en de regel van Coombs.

Als we daarbij afzien van de vraag of we kiezers nu wel of niet willen verzoeken al hun voorkeuren op te geven (de zesde eis), lijkt er ten minste één regel te zijn die het op de hiervoor genoemde punten ten minste even goed doet en op sommige punten zelfs beter: de aangevulde regel van Copeland.

\section{De werking van de aangevulde regel van Copeland}

De (aangevulde) regel van Copeland is de vijfde regel die we in dit stuk bespreken (Dummett I997, 77). ${ }^{22}$ Hiervoor maken we weer gebruik van ons leidende voorbeeld (zie tabel I en 2). Voor elk van de kandidaten gaan we na het uitbrengen van de stemmen eerst na of zij het in een paarsgewijze verkiezing zouden winnen van een andere kandidaat. Elke overwinning levert een kandidaat I punt op. In ons voorbeeld verslaat kandidaat $a$ alle drie de andere kandidaten in paarsgewijze verkiezingen. Kandidaat $a$ wint dus 3 punten. Het totale aantal punten dat een kandidaat op die manier haalt, noemen we de Copelandscore. Als een van de kandidaten de hoogste Copelandscore heeft, wordt hij burgemeester. In ons voorbeeld heeft kandidaat $z$ een Copelandscore van I en kandidaat $y$ een Copelandscore van 2. Kandidaat $x$, de condorcetverliezer, heeft een score van o.
Het risico bestaat dat twee (of meer) kandidaten een even hoge Copelandscore hebben. Dit gebeurt als er geen condorcetwinnaar bestaat. ${ }^{23}$ Als er een meerderheidswinnaar of een condorcetwinnaar is, wijst de Copelandscore die ook aan. Maar als er geen condorcetwinnaar is, kunnen twee of meer kandidaten dezelfde Copelandscore krijgen. Daarom is een aanvulling nodig op het simpele gebruik van de Copelandscore. Om die aanvulling uit te leggen, voeren we een nieuw voorbeeld op, waarbij er géén condorcetwinnaar bestaat.

Tabel 3: Voorkeuren van drie groepen kiezers voor drie burgemeesterkandidaten

\begin{tabular}{|l|c|c|c||c|c|c|}
\hline Groep & $\mathrm{m}$ & $\mathrm{n}$ & $\mathrm{p}$ & & $\begin{array}{c}\text { Copeland- } \\
\text { score }\end{array}$ & $\begin{array}{c}\text { Borda- } \\
\text { score }\end{array}$ \\
\hline Omvang & $40 \%$ & $35 \%$ & $25 \%$ & \multicolumn{3}{|c|}{ Kandidaat } \\
\hline $1^{\text {ste }}$ voorkeur & a & c & b & A & 1 & 115 \\
\hline $2^{\text {de }}$ voorkeur & b & a & c & B & 1 & 90 \\
\hline $3^{\text {de }}$ voorkeur & c & b & a & C & 1 & 95 \\
\hline
\end{tabular}

In dit voorbeeld zijn de voorkeuren voor de drie kandidaten zo verdeeld dat alle drie de kandidaten een Copelandscore van I hebben. Op basis van de Copelandscore komen we dan ook niet tot de keuze voor een burgemeesterskandidaat. Daarom berekenen we voor de kandidaten met de hoogste Copelandscore (in dit geval dus alle drie) ook de zogenaamde Bordascore. Een kandidaat die onderaan staat, krijgt o punten, een kandidaat die de op één na laatste plek inneemt krijgt I punt, et cetera. Dat betekent dat kandidaat $c(40 \times 0+35 \times 2+25 \times$ $\mathrm{I}=) 95$ punten krijgt. De kandidaten $a$ en $b$ krijgen respectievelijk $(40 \times 2+35 \times \mathrm{I}+25 \times 0=)$ II 5 en $(40$ $\mathrm{xI}+35 \times 0+25 \times 2=) 90$ punten. Van de kandidaten met de hoogste Copelandscore wordt de kandidaat met de hoogste Bordascore burgemeester. ${ }^{24}$ In dit geval is dat dus kandidaat $a$.

\section{Een beoordeling van de aangevulde regel van Copeland}

Het valt eenvoudig in te zien dat een meerderheidswinnaar (als die bestaat) en een condorcetwinnaar (als die bestaat) alle paarsgewijze verkiezingen winnen en dus altijd de meeste punten 
krijgen. Een condorcetverliezer krijgt geen enkele punt en verliest dus altijd. De aangevulde regel van Copeland voldoet dus aan de eerste drie criteria. Ook voldoet deze regel aan de eis van monotoniciteit: kandidaten zouden achteraf nooit liever iets minder stemmen hebben gehad.

Het vermoeden bestaat wel dat de regel iets vatbaarder is voor strategisch gedrag dan het tweerondenstelsel en alternative vote, maar kiezers moeten veel weten over de voorkeuren van andere kandidaten om strategisch zinvol te kunnen handelen (Nurmi i987, 124).

Voor kiezers wijkt deze regel niet af van andere stelsels waarbij zij hun preferenties moeten opgeven. Ook hoeven ze nooit meer dan één keer naar de stembus. Dat maakt de organisatie van de verkiezingen voor de overheid gemakkelijker dan een tweerondesysteem. ${ }^{25}$

We hebben in deze bijdrage nu in totaal vijf procedures met elkaar vergeleken op basis van zeven criteria. In tabel 4 zijn de resultaten van deze vergelijking nog eens op een rijtje gezet.

\section{Wat te doen?}

De introductie van een gekozen burgemeester is een unieke procedure, die wellicht een standaard zet voor latere veranderingen in het Nederlandse staatsbestel. Zoals in de inleiding tot dit artikel al werd opgemerkt, beperkt de discussie over de procedure zich vooralsnog tot het tweerondenstelsel en alternative vote. Uit de analyse van beide stelsels in deze bijdrage blijkt datzij elkaar op vijf van de zeven criteria nauwelijks ontlopen. Beide stelsels selecteren altijd een meerderheidswinnaar (eis I), selecteren nooit een condorcetverliezer (eis 3) en zijn niet zeer makkelijk strategisch te manipuleren (eis 5). Verder hebben beide stelsels de eigenschap dat ze soms de condorcetwinnaar niet selecteren (eis 2) en schenden ze de eis van monotoniciteit (eis 4).

In dit licht is het niet vreemd dat het ministerie van BZK een voorkeur uitspreekt voor het tweerondenstelsel. In het licht van de zesde eis, eenvoud, scoort dat namelijk beter. Kiezers hoeven hierbij immers alleen hun eerste voorkeur te geven, en dat is makkelijker dan het ordenen van alle kandidaten. Daar staat wel tegenover dat zij bij het tweerondesysteem soms twee keer naar de stembus moeten en dat de lokale overheid soms twee verkie- zingen moet organiseren (zevende eis).

Dat de uitkomst van de afweging tussen het tweerondesysteem en alternative vote in het voordeel van het eerste uitvalt als we ons beperken tot de hier behandelde criteria en niet te veel nadruk leggen op de uitvoerbaarheid (de zevende eis), mag echter niet doen vergeten dat er meer procedures mogelijk zijn. In deze bijdrage is vooral aandacht gevraagd voor de aangevulde regel van Copeland. Deze regel voldoet volledig aan vijf van de zeven eisen en is bovendien niet gemakkelijk strategisch te manipuleren.

Nadeel van de regel ten opzichte van het tweerondenstelsel is wellicht dat kiezers wordt gevraagd niet alleen op te geven wie van de kandidaten zij de beste vinden, maar ook wie zij op de tweede, derde, et cetera plaats zetten. Om een procedure te hebben die altijd een condorcetwinnaar oplevert en monotoon is, moet dus een offer worden gebracht. Dat offer bestaat in dit geval uit het (wellicht niet voor iedereen even eenvoudige) verzoek om aan te geven wat men denkt van álle beschikbare burgemeesterskandidaten.

De hierboven gepresenteerde analyse maakt echter ook duidelijk dat er áltijd offers moeten worden gebracht. Als men niet bereid is meer aan kiezers te vragen dan hun eerste voorkeur, accepteert men dat er in sommige gemeenten een burgemeester wordt gekozen die door een (grote) meerderheid van de bevolking minder wordt gewaardeerd dan een verliezende kandidaat (de condorcetwinnaar). Ook wordt dan geaccepteerd dat een verliezer had kunnen winnen als hij mínder stemmen zou hebben gehaald (monotoniciteit). De uitkomsten kunnen wellicht 'ondemocratisch' worden gevonden.

In de discussie over de manier waarop de burgemeester moet worden gekozen, moet altijd in het oog worden gehouden dat de perfecte regel niet bestaat. Elke regel heeft voor- en nadelen. In de discussie over de gekozen burgemeester moet dan ook altijd duidelijk worden gemaakt welke eisen absoluut worden gesteld en welke offers men bereid is daarvoor te brengen. Dat die discussie gevoerd moet worden, lijkt evident. In dit stuk is hieraan een eerste bijdrage geleverd. 
Henk van der Kolk Hoe kiezen we straks de burgemeester?

Tabel 4: In welke mate voldoen de verschillende procedures aan de gestelde eisen?

\begin{tabular}{|c|c|c|c|c|c|}
\hline $\begin{array}{l}\text { Regels besproken in de tekst } \\
\text { Beoordelingscriteria besproken in de tekst }\end{array}$ & $\begin{array}{l}\text { Meerderheids- } \\
\text { Regel }\end{array}$ & $\begin{array}{c}\text { Tweeronde- } \\
\text { systeem (2RS) }\end{array}$ & $\begin{array}{l}\text { Alternative } \\
\text { vote }(\mathrm{AV})\end{array}$ & $\begin{array}{l}\text { Regel van } \\
\text { Coombs }\end{array}$ & $\begin{array}{l}\text { Aangevulde } \\
\text { regel van } \\
\text { Copeland }\end{array}$ \\
\hline $\begin{array}{l}\text { 1. Wordt de kandidaat die door meer dan } 50 \\
\text { procent van de kiezers het meest wordt } \\
\text { gewaardeerd (meerderheidswinnaar) altijd } \\
\text { gekozen tot burgemeester? }\end{array}$ & $\mathrm{Ja}$ & $\mathrm{Ja}$ & Ja & Ja & Ja \\
\hline $\begin{array}{l}\text { 2. Wordt de kandidaat die het in een paarsge- } \\
\text { wijze vergelijking wint van alle andere kandi- } \\
\text { daten (condorcetwinnaar) áltijd gekozen tot } \\
\text { burgemeester? }\end{array}$ & $\begin{array}{c}\text { Nee, heel vaak } \\
\text { niet }\end{array}$ & $\begin{array}{c}\text { Nee, vrij vaak } \\
\text { niet }\end{array}$ & $\begin{array}{l}\text { Nee, vrij vaak } \\
\text { niet }\end{array}$ & $\begin{array}{c}\text { Nee, maar } \\
\text { veel beter dan } \\
2 \mathrm{RS} \text { en } \mathrm{AV}\end{array}$ & Ja \\
\hline $\begin{array}{l}\text { 3. Wordt de kandidaat die het in een paarsge- } \\
\text { wijze vergelijking verliest van alle andere kan- } \\
\text { didaten (condorcetverliezer) nóóit gekozen } \\
\text { tot burgemeester? }\end{array}$ & Nee & $\mathrm{Ja}$ & Ja & Ja & $\mathrm{Ja}$ \\
\hline $\begin{array}{l}\text { 4. Heeft een kandidaat er altijd belang bij om } \\
\text { méér stemmen te winnen? (monotoniciteit) }\end{array}$ & Ja & Nee & Nee & Nee & Ja \\
\hline $\begin{array}{l}5 . \text { Is de regel vatbaar voor strategisch gedrag } \\
\text { van (groepen) kiezers? }\end{array}$ & Ja (veel) & $\begin{array}{l}\text { Ja, maar } \\
\text { weinig }\end{array}$ & $\begin{array}{l}\text { Ja, wellicht } \\
\text { iets beter dan } \\
\text { bij } 2 \text { RS }\end{array}$ & $\begin{array}{l}\text { Ja, wellicht } \\
\text { iets beter dan } \\
\text { bij } 2 \text { RS }\end{array}$ & $\begin{array}{l}\text { Ja, maar vrij } \\
\text { weinig }\end{array}$ \\
\hline $\begin{array}{l}\text { 6. Hoeven kiezers alleen op te geven welke } \\
\text { kandidaat zij de beste vinden? }\end{array}$ & Ja & Ja & Nee & Nee & Nee \\
\hline 7. Hoeft er maar één keer gestemd te worden? & Ja & $\begin{array}{l}\text { Nee, soms } \\
\text { niet }\end{array}$ & Ja & Ja & Ja \\
\hline
\end{tabular}

\section{Noten}

I Zo werd bijvoorbeeld in het strategisch akkoord van het CDA-VVD-LPF-kabinet met geen woord gerept over dit onderwerp. Pas in de Verkennende notie over de invoering van de direct gekozen burgemeester van I4 januari 2003 wordt voor het eerst kort ingegaan op dit onderwerp. In de hoofdlijnennotitie van september 2003 en de daarop volgende adviesronde wordt iets meer ingegaan op dit onderwerp.

2 Uiteraard is het onderstaande niet uitsluitend van toepassing op burgemeestersverkiezingen. Ook bij de selectie van bijvoorbeeld een partijleider door de leden van die politieke partij wordt een procedure gehanteerd. Bij de verkiezing van Wouter Bos tot partijleider van de PvdA werd bijvoorbeeld het in de hoofdtekst te bepreken systeem van alternative vote gehanteerd.

3 Als second best noemt de kiesraad supplementary vote. Dit stelsel wordt hier niet behandeld. Zie voor een globale kritiek Van der Kolk 2003.

4 Loterijen of benoemingen door Commissaris van de Koningin of benoemingen door mij zijn ook inzichtelijk en eenvoudig. Deze procedures worden door het ministerie niet genoemd. Het lijkt er dus op dat er impliciet nog andere criteria worden gehanteerd.

5 Voor de duidelijkheid zij opgemerkt dat het hanteren van een tweerondesysteem waarbij in de tweede ronde maar twee kandidaten meedoen niet gevrijwaard is van de hierna in de hoofdtekst gesignaleerde problemen. De beoordeling van het tweerondesysteem betreft natuurlijk de manier waarop de selectie van een burgemeester uit álle deelnemende kandidaten plaatsvindt. Dat zijn er in veel gevallen meer dan twee. Ook procedures waarbij bijvoorbeeld de gemeenteraad de keuze voor kiezers vereenvoudigt tot twee kandidaten lossen het probleem niet op. Dergelijke procedures verplaatsen slechts het probleem naar de gemeenteraad.

6 Het voorbeeld is zo geconstrueerd dat de vier te bespreken procedures vier verschillende uitkomsten opleveren. Uiteraard is het niet zo dat dit altijd het geval is.

7 Zoals eerder is opgemerkt, gebruikte de PvdA in 2002 deze procedure om de nieuwe partijleider te kiezen.

8 Het gaat hierbij om een speciaal geval van single transferable vote (STV). Bij STV worden verscheidene kandidaten geko- 
zen, terwijl bij alternative vote slechts één kandidaat wordt gekozen.

9 Het is níet noodzakelijk dat kiezers álle kandidaten in volgorde plaatsen. Op de complicatie dat kiezers dat soms wel en soms niet zullen doen - een complicatie die bij een praktische invoering bij een systeem van preferente stemmen wel aandacht dient te krijgen - gaan we in deze bijdrage verder niet in.

Io De meerderheidswinnaar is natuurlijk altijd een condorcetwinnaar, maar een condorcetwinnaar hoeft niet ook meerderheidswinnaar te zijn.

II Een probleem bij de beoordeling van stemprocedures is onder meer dat ook condorcetwinnaars niet altijd bestaan. De kans dat een condorcetwinnaar niet bestaat, is uiteraard kleiner dan de kans dat een meerderheidswinnaar niet bestaat, maar nog altijd substantieel. De kans wordt onder bepaalde omstandigheden groter als het aantal burgemeesterskandidaten en als het aantal kiezers toenemen. Riker (I982) presenteert wat berekeningen gebaseerd op de veronderstelling dat álle voorkeuren van burgers voor kandidaten met een even grote kans kunnen voorkomen. Hij concludeert onder meer dat als het electoraat heel groot is en het aantal alternatieven (kandidaten) 3, de kans op het ontbreken van een condorcetwinnaar 9 procent is. Als het aantal kandidaten 6 is, neemt die kans toe tot 32 procent (zie ook Merrill I984, 28)! Als de voorkeuren voor burgemeesterskandidaten ééntoppig zijn (en het aantal kiezers is oneven) bestaat altijd een condorcetwinnaar.

I2 De tweede en derde eis zijn niet equivalent. Soms is er namelijk wel een condorcetwinnaar, maar geen condorcetverliezer, en soms is er geen condorcetwinnaar, maar wel een condorcetverliezer. De eis dat altijd de condorcetwinnaar moet worden gekozen, impliceert dus niet dat nooit de condorcetverliezer wordt gekozen. En de eis dat de condorcetverliezer nooit wordt gekozen, impliceert niet dat met die procedure altijd de condorcetwinnaar wordt gekozen.

I3 Voor een inleiding in strategisch stemmen kan worden begonnen met Van Hees I998, I22-I25.

I4 Zie Nurmi i983; Nurmi I987 en Fedrizzi, Kacprzyk e.a. I996 voor een uitvoeriger vergelijking van procedures.

I5 Voor een inleiding wordt verwezen naar Nurmi I987 en Mueller I989.

I6 Volgens een van die methoden somt men voor een aantal kiezers alle mogelijke profielen (analoog aan tabel I) over enkele kandidaten op (of neemt met een selectie daaruit). Daarna selecteert men de profielen met een condorcetwinnaar. Ten slotte berekent men hoe vaak een bepaalde procedure de condorcetwinnaar selecteert. Nadeel van deze procedure is dat ook heel belachelijke profielen in de berekening worden meegenomen. Ideale oplossingen voor dit probleem bestaan echter niet. De hier gepresenteerde opmerkingen over de mate waarin condorcetwinnaars worden geselecteerd, zijn gebaseerd op het toepassen van deze methode.

I7 Nog meer dan bij onderzoek naar de mate waarin de eis wordt geschonden dat altijd de condorcetwinnaar moet worden geselecteerd, zijn de conclusies over de vatbaarheid van regels voor strategisch stemmen gebaseerd op onderzoek dat nog in de kinderschoenen staat.

I8 Uit het eerder genoemde onderzoek van Merrill blijkt dat, net als bij de meerderheidsregel, de kans op het selecteren van een ander dan de condorcetwinnaar toeneemt als er meer kandidaten zijn.

I9 Of deze regel net zo gemakkelijk is te manipuleren als alternative vote is omstreden. Nurmi plaatst bijvoorbeeld beide regels in dezelfde categorie. Maar Dummett denkt dat deze regel vatbaarder is voor manipulatie omdat kiezers de gelegenheid krijgen de eerste keer iets anders op te geven dan de tweede keer (Dummett I997: 90).

20 In het handboek van IDEA wordt gepleit voor het tweerondesysteem ten faveure van alternative vote in 'illiterate societies': 'Because electors do not have to rank-order candidates with numbers to express their second choice, (the two round system) may be better suited to countries with widespread illiteracy than systems which use preferential numbering like the Alternative Vote'(Reynolds en Reilly I997, 44). In hetzelfde handboek wordt gewaarschuwd tegen het onderschatten van de kiezer (Reynolds en Reilly I997, I22).

2I Voor een overzicht van verschillende procedures wordt verwezen naar overzichtswerken op het gebied van verkiezingsprocedures (Riker I982; Nurmi I983; Dummett I984; Nurmi I987; Reynolds en Reilly I997).

22 Dummett houdt een pleidooi voor dit, wat hij noemt, 'composite system' en besteedt veel aandacht aan de manier waarop de uitslag moet worden gepresenteerd. In deze bijdrage gaan we daar verder niet op in.

23 Zie voor de kans dat er geen condorcetwinnaar bestaat ook voetnoot II.

24 Men zou zich natuurlijk kunnen afvragen waarom we dan niet direct de Bordascore berekenen en de zogenaamde Bordaregel gebruiken. De Bordaregel garandeert echter níet dat altijd de meerderheidskandidaat of de condorcetwinnaar worden geselecteerd (Riker I982; Nurmi i987).

25 Tegenover deze voordelen staat de wellicht nadelig gevonden eigenschap dat de aangevulde regel van Copeland op een complexe wijze tot een winnaar komt nadat de stemmen zijn uitgebracht. Dat maakt deze regel wellicht weinig inzichtelijk en maakt het moeilijk in een klein aantal gevallen om kiezers uit te leggen waarom deze kandidaat heeft gewonnen.

\section{Literatuur}

BZK, 2003a, Verkennende notitie invoering direct gekozen burgemeester, Den Haag:

Ministerie van Binnenlandse Zaken en Koninkrijksrelaties BZK, 2003b, Hooflijnennotitie direct gekozen burgemeester, Den Haag: Ministerie van Binnenlandse Zaken en Koninkrijksrelaties
BZK (2003c), Brief aan de Tweede Kamer over de reactie op commentaar inzake de hoofdlijnennotitie gekozen burgemeester, Den Haag: Ministerie van Binnenlandse Zaken en Koninkrijksrelaties

Doron, G. en R. Kronick, I977, 'Single transferrable vote, an example of a perverse social choice function'. American 
Journal of Political Science 2I(2), 303-3II

Dummett, M., I984, Voting Procedures, Oxford: Clarendon Press

Dummett, M., I997, Principles of Electoral Reform, Oxford: Oxford University Press

Fedrizzi, M., J. Kacprzyk e.a., I996, 'How different are social choice functions, a rough sets approach'. Quality Q Quantity 30 (I), 87-99

Felsenthal, D.S. en M. Machover, I995, 'Who ought to be elected and who is actually elected - an empirical investigation of 92 elections under 3 procedures'. Electoral Studies

I4 (2), I43-169

Felsenthal, D.S., Z. Maoz e.a., I993, 'An empirical evaluation of six voting procedures, do they really make any difference?'. British Journal of Political Science 23(I), I-27

Kiesraad, 2003, Advies gekozen burgemeester: 0000017677 , Den Haag

Kummeling, H. en H. van der Kolk, 2002, Lokale kiesstelsels vergeleken: over de vormgeving, het gebruik en de consequenties van lokale kiesstelsels, Den Haag: VNG Uitgeverij

Merrill, S., III, I984, 'A comparison of efficiency of multi- candidate electoral systems'. American Journal of Political Science 28 (I), 23-48

Mueller, D.C., I989, Public choice II, a revised edition of public choice, Cambridge etc.: Cambridge University Press

Nurmi, H., I983, Voting procedures: a summary analysis'. British Journal of Political Science I3 (2), I8I-208

Nurmi, H., I987, Comparing voting systems, Dordrecht etc.: D. Reidel Publishing Company

Reynolds, A. en B. Reilly, I997, The international IDEA handbook of electoral system design, Stockholm: International Institute for Democracy and Electoral Assistance (IDEA) Riker, W.H., I982, Liberalism against populism; a confrontation between the theory of democracy and the theory of social choice, San Francisco: W.H. Freeman and Company

Van der Kolk, H., 2003, 'Supplementary vote draagt niet bij legitimatie van rechtstreeks gekozen burgemeester'. Nederlands Juristenblad 78 (42), 2202-2203

Van Hees, M., I998, 'Individuele voorkeuren en individuele beslissingen'. In: H. Pellikaan en W. Hout, Economische modellen en politieke besluitvorming. Inleiding in de rationelekeuzetheorie, Bussum: Uitgeverij Countinho, I03-I30 